\title{
PENGARUH KEPEMIMPINAN KEPALA SEKOLAH DAN IKLIM KERJA SEKOLAH TERHADAP KINERJA GURU
}

\author{
Carudin \\ SMKN 1 Gabuswetan \\ Jl. PU. Rancahan Kec. Gabuswetan Kab. Indramayu 452563 \\ Email: carudin@yahoo.co.id
}

\begin{abstract}
Abstrak: Peningkatan kinerja mengajar guru dapat dilakukan melalui peningkatan kepemimpinan kepala sekolah dan iklim kerja sekolah. Penelitian ini bertujuan: (a) untuk mengetahui kepemimpinan kepala sekolah, iklim kerja sekolah, dan kinerja guru, (b) untuk mengetahui seberapa besar pengaruh kepemimpinan kepala sekolah dan iklim kerja sekolah terhadap kinerja guru. Hasil penelitian yang diperoleh kepemimpinan kepala SMK Negeri se-Kabupaten Indramayu yang meliputi dimensi kepribadian, kemampuan pengambilan keputusan, kemampuan berkomunikasi, memberi motivasi dan pendelegasian wewenang memberikan pengaruh cukup terhadap kinerja. Iklim kerja sekolah mempunyai hubungan yang cukup berpengaruh terhadap kinerja guru. Kinerja mengajar guru berada pada kategori cukup baik. Kepemimpinan kepala sekolah berpengaruh positif terhadap kinerja guru tetapi kurang cukup memotivasi kinerja guru. Pengaruh iklim kerja sekolah terhadap kinerja guru kurang cukup baik dan dapat memotivasi kinerja guru. Kepemimpinan kepala sekolah dan iklim kerja memberikan pengaruh positif yang signifikan terhadap kinerja guru.
\end{abstract}

Kata kunci: Kinerja guru, kepemimpinan kepala sekolah, iklim kerja

\begin{abstract}
Improvement in teachers' teaching performance can be achieved by improving school leadership and school climate. This study aims: (a) to investigate the school leadership, school climate, and teacher's performance, (b) to know how great the influence of school leadership and school climate on teacher's performance. The study shows that the school principal leadership of State Vocational School (SMK) in Indramayu Regency, which includes dimensions of personality, decision-making ability, ability to communicate, motivate and delegate an authority, provides fair influence on performance. School climate also has fair influence on the performance of teachers. Teachers' performance is in fair category. School leadership has a positive effect on the performance of teachers but is not enough (less fair) to motivate the performance. The school climate has less fair influence on teacher's performance and can motivate the performance. School leadership and climate provide a significant positive impact on teacher's performance.
\end{abstract}

Key words: teacher's performance, school leadership, school climate.

\section{PENDAHULUAN}

Pendidikan adalah salah satu institusi yang berperan menyiapkan sumber daya manusia. Sejalan dengan perkembangan zaman, tantangan yang dihadapi sistem pendidikan semakin meningkat baik kualitas, kuantitas maupun relevansinya. Perkembangan masyarakat yang diikuti dengan perkembangan kebutuhannya memunculkan jenis dan bentuk pekerjaan baru yang memerlukan penyesuaian spesifikasi kemampuan dan persyaratan dari tenaga kerjanya, As'ari (2008: 1-2 ). Arus globalisasi menimbulkan tantangan daya saing terhadap produk barang dan jasa. Sistem pendidikan yang bermutu akan mampu meningkatkan kualitas sumber daya manusia. Pada akhirnya kualitas produk barang dan jasa menjadi meningkat sehingga diharapkan mampu menjadi tuan rumah di negerinya sendiri dan dapat bersaing di pasar global. 
Guru merupakan faktor sentral di dalam sistem pembelajaran terutama di sekolah. Semua komponen lain, mulai dari kurikulum, sarana-prasarana, biaya, dan sebagainya tidak akan banyak berarti apabila keutamaan pembelajaran yaitu interaksi guru dengan peserta didik tidak berkualitas. Semua komponen lain, terutama kurikulum akan "hidup" apabila dilaksanakan oleh guru. Peranan guru sangat penting dalam mentransformasikan input pendidikan, sehingga dapat dipastikan bahwa di sekolah tidak akan ada perubahan atau peningkatan kualitas tanpa adanya perubahan dan peningkatan kualitas guru. Hal ini berarti, pendidikan yang baik dan unggul tetap akan bergantung pada kondisi mutu guru. UNESCO menyatakan bahwa "memperbaiki mutu pendidikan pertama-tama tergantung pada perbaikan perekrutan, pelatihan, status sosial, dan kondisi para guru; mereka membutuhkan pengetahuan dan keterampilan, karakter personal, prospek professional, dan motivasi yang tepat jika ingin memenuhi harapan stakeholder" (Delors, 1996).

Kinerja guru yang diharapkan dapat mendongkrak kualitas dan relevansi pendidikan, dalam implementasinya di lapangan tergantung dari banyak faktor yang mempengaruhinya dan saling berkaitan, misalnya faktor kepemimpinan kepala sekolah dan iklim kerja. Kepemimpinan kepala sekolah sangat menentukan mutu, tanpa kepemimpinan yang baik proses peningkatan mutu tidak dapat dilakukan dan diwujudkan (Edwar Sallis, 2006:170). Keutamaan pengaruh (influence) kepemimpinan kepala sekolah bukanlah semata-mata berbentuk instruksi, melainkan lebih merupakan motivasi atau pemicu (trigger) yang dapat memberi inspirasi terhadap para guru dan karyawan, sehingga inisiatif dan kreatifitasnya berkembang secara optimal untuk meningkatkan kinerjanya, (Tjutju Yuniarsih dan Suwatno, 2008:166). Kenyataan di lapangan kepemimpinan kepala sekolah masih menunjukan kinerjanya yang belum optimal, hal itu di indikasikan antara lain masih minimnya kepala sekolah untuk melakukan kegiatan supervisi dan tingkat kepuasan guru terhadap kepemimpinan kepala sekolah masih rendah.

Menurut Gibson, Ivancevich dan Donelly (1992), iklim organisasi adalah serangkaian keadaan lingkungan yang dirasakan secara langsung dan tidak langsung oleh karyawan. Hal ini menggambarkan bahwa iklim organisasi sebagai beberapa keadaan atau kondisi dalam satu rangkaian yang secara langsung atau tidak langsung, sadar atau tidak sadar, dapat mempengaruhi karyawan. Iklim kerja yang sejuk dan harmonis akan memberikan gairah dan inspirasi dalam bekerja. Kenyataan yang ada iklim kerja SMK Negeri di seluruh Indramayu secara umum masih menunjukan gejala yang belum optimal. Selain sarana-prasarana sekolah yang belum representatif, juga manajemen sekolah yang secara umum kurang memuaskan stakeholder sekolah. 
Mengingat pentingnya peranan guru, maka kinerja guru harus selalu dikontrol dan ditingkatkan. Sayangnya, dalam kultur masyarakat Indonesia sampai saat ini pekerjaan guru masih cukup tertutup. Bahkan atasan guru seperti kepala sekolah dan pengawas sekali pun tidak mudah untuk mendapatkan data dan mengamati realitas keseharian performance guru di hadapan siswa. Guru berusaha menampakkan kinerja terbaiknya, baik pada aspek perencanaan maupun pelaksanaan pembelajaran hanya pada saat dikunjungi. Selanjutnya guru akan kembali bekerja seperti sedia kala, kadang tanpa persiapan yang matang serta tanpa semangat dan antusiasme yang tinggi. Berdasarkan latar belakang masalah dapat dirumuskan masalah penelitian, yaitu: bagaimana kepemimpinan, iklim kerja, kinerja guru dan hubungan diantara faktor-faktor tesebut di SMK Negeri di Indramayu. Penelitian ini bertujuan untuk mendeskripsikan kepemimpinan para kepala SMK Negeri di Indramayu, iklim kerja, dan kinerja guru kejuruan. Selain itu, mencari hubungan dan pengaruh antara kepemimpinan kepala sekolah terhadap kinerja guru; iklim kerja sekolah terhadap kinerja guru; kepemimpinan kepala.

Menurut Veithzal Rivai (2009), kinerja adalah perilaku yang nyata yang ditampilkan setiap orang sebagai prestasi kerja sesuai dengan peranannya. Kinerja merupakan suatu wujud prilaku seseorang atau organisasi dengan orientasi prestasi. Kinerja guru dapat dilihat dan diukur berdasarkan spesifikasi kompetensi yang harus dimiliki oleh guru. Indikator penilaian terhadap kinerja guru dilakukan terhadap tiga kegiatan pembelajaran dikelas yaitu: Perencanaan kegiatan pembelajaran, kegiatan pembelajaran dan evaluasi pembelajaran.

Kepala sekolah adalah seorang guru yang seharusnya mempunyai kemampuan untuk memimpin segala sumber daya yang ada pada suatu sekolah sehingga dapat didayagunakan secara maksimal untuk mencapai tujuan bersama. Berdasarkan Peraturan Menteri Pendidikan Nasional No. 13 Tahun 2007 tanggal 17 April 2007 Tentang Standar Kepala Sekolah/Madrasah, kepala sekolah harus memiliki kompetensi yakni: kompetensi kepribadian, kompetensi manajerial, kompetensi kewirausahaan, kompetensi supervisi, dan kompetensi sosial. Kelima standar kompetensi tersebut terintegrasi di dalam kinerja kepala sekolah.

Urgensi dan signifikansi fungsi dan peranan kepala sekolah didasarkan pada pemahaman bahwa keberhasilan sekolah merupakan keberhasilan kepala sekolah. Oleh karena itu, kepala sekolah perlu memiliki kompetensi yang disyaratkan agar dapat merealisasikan visi dan misi yang diemban sekolahnya. Dalam paradigma baru manajemen pendidikan, kepala sekolah minimal harus mampu berfungsi sebagai edukator, manager, administrator, supervisor, leader, inovator dan motivator (EMASLIM). 
Kepala sekolah sebagai pemimpin harus mampu mengambil keputusan yang cepat dan tepat, memberikan petunjuk dan pengawasan, meningkatkan kemauan dan kemampuan tenaga kependidikan, membuka komunikasi dua arah dan mendelegasikan tugas. Wahjosumijo (1999), mengemukakan bahwa kepala sekolah sebagai pemimpin harus memiliki karakter khusus yang mencakup kepribadian, keahlian dasar, pengalaman dan pengetahuan profesional, serta pengetahuan administrasi dan pengawasan. Hal ini menggambarkan bahwa iklim organisasi sebagai beberapa keadaan atau kondisi dalam satu rangkaian yang secara langsung atau tidak langsung, sadar atau tidak sadar, dapat mempengaruhi karyawan. Iklim kerja terdiri dari iklim secara fisik dan iklim secara psikologis. Secara fisik misalnya keamanan, kebersihan, kenyamanan, kondisi sarana dan prasarana organisasi (sekolah). Iklim psikologis meliputi lima dimensi, yaitu: Responsibility (tanggung jawab), identity (identitas), warmth (kehangatan), support (dukungan), dan conflict (konflik).

\section{METODE}

Metode yang digunakan dalam penelitian ini adalah penelitian deskriptif yang mengungkapkan keadaan obyek penelitian sebagaimana adanya di lapangan tentang kepemimpinan kepala sekolah, iklim bekerja dan kinerja guru. Pengambilan data dilakukan dengan menggunakan angket yang disebarkan kepada sguru kejuruan di SMK Negeri seKabupaten Indramayu tahun pelajaran

2010/2011 sebanyak 85 orang.

Analisis data dilakukan dengan mengumpulkan data, mengklasifikasikan data berdasarkan item, indikator pada variabel penelitian. Penyajian data hasil penelitian disampaikan dalam bentuk histogram agar lebih mudah dipahami, dan menyimpulkan hasil penelitian. Perhitungan yang digunakan yaitu rerata, standar deviasi, median dan modus. Statistik deskriptif digunakan untuk mendeskripsikan data variabel kepemimpinan kepala sekolah, iklim kerja sekolah, dan kinerja guru.

\section{HASIL PENELITIAN}

Kepemimpinan kepala sekolah secara umum pada SMK Negeri se-Kabupaten Indramayu menurut 85 persepsi guru produktif yang dijadikan responden yakni kepemimpinan kepala sekolah berada pada kecenderungan umum kategori sedang $(62,7 \%)$ dari skor ideal. Dengan rincian kepribadian kepala sekolah 66,73\%, kemampuan pengambilan keputusan $61 \%$, kemampuan berkomunikasi dengan guru 61,3\%, dan kemampuan memberi motivasi dan pendelegasian wewenang $58,9 \%$. 
Kepemimpinan kepala sekolah secara umum berpengaruh positif terhadap kinerja guru sebesar 0,260 dengan kontribusi sebesar 6,7 \%. Sisanya dipengaruhi oleh faktor lain $91 \%$. Signifikansi peningkatan sebesar 0,016. $F_{\text {hit }}$ 6,002 dan $F_{\text {tab }} 3,107$, maka Hi diterima dan menolak Ho. Persamaan regresi yang terbentuk adalah $\hat{Y}=70,65+0,26 X_{1}$. Hasil uji t, diperoleh $t_{\text {hit }}=2,45$, sedangkan $t_{\text {tab }}$ sebesar 1,989. Dengan demikian kepemimpinan kepala sekolah berpengaruh posistif yang signifikan terhadap kinerja guru.

Iklim kerja sekolah di SMK Negeri se-Kabupaten Indramayu berada pada kecenderungan umum kategori sedang $(62,7 \%)$ dari skor ideal. Dengan iklim kerja sekolah secara fisik $61,2 \%$, dan iklim kerja sekolah secara psikologis $63,73 \%$ dari sekor ideal. Iklim kerja sekolah memberikan pengaruh positif terhadap kinerja guru sebesar 0,361 tergolong rendah dengan kontribusi sebesar 13\%. Sisanya dipengaruhi oleh faktor lain. Signifikansi peningkatan sebesar 0,001. $\mathrm{F}_{\text {hit }} 12,432$ dan $\mathrm{F}_{\text {tab }} 3,107$, dengan menerima Hi dan menolak Ho.

Kinerja guru berada pada kecenderungan umum kategori cukup baik $78 \%$ dari skor ideal. Dengan rincian dimensi perencanaan pembelajaran pada kategori skor cukup baik $(74,9$ $\%)$, pelaksanaan pembelajaran dan evaluasi pada kategori sedang $(68,3 \%)$. Persamaan regresi yang terbentuk adalah $\hat{Y}=64,081+0,361 X_{2}$. Hasil uji $t$, diperoleh $t=3,526$, sedangkan $\mathrm{t}_{\text {tab }}$ pada taraf signifikan 0,05 didapat nilai sebesar 1,989. Dengan demikian, iklim kerja sekolah berpengaruh positif yang signifikan terhadap kinerja guru.

Kepemimpinan kepala sekolah dan iklim kerja sekolah secara simultan memberikan pengaruh positif yang signifikan terhadap kinerja guru. Pengaruh kepemimpinan kepala sekolah dan iklim kerja terhadap kinerj aguru sebesar 0.388 tergolong rendah. Sedangkan kontribusi kedua varianel tersebut secara simultan terhadap adalah $15,1 \%$, sisanya oleh faktor lain. Peningkatan memenuhi signifikansi 0,01 dengan harga $F$ hitung 7,274 dan $F$ tabel 1,989, artinya hasil persamaan regresi yang telah didapat adalah signifikan. Hipotesis alternatif (Hi) diterima dan menolak hipotesis 0 (Ho). Persamaan regresi yang terbentuk adalah: $\hat{Y}=27,316$ $+0,144 X_{1}+0,315 X_{2}$. Hal ini menunjukan bahwa secara sederhana kepemimpinan kepala sekolah dan iklim kerja berpengaruh positif terhadap kinerja guru yang tercermin dari nilai prediksi perubahan nilai di atas.

\section{PEMBAHASAN}

Hasil penelitian menunjukan bahwa kepemimpinan kepala SMK Negeri di seluruh Kabupaten Indramayu hanya mencapai kategori sedang. Persentasi paling tinggi pada dimensi kepribadian termasuk kategori sedang. Persentasi terkecil ada pada dimensi kemampuan memberi motivasi dan pendelegasian wewenang. Berdasarkan data pilihan 
responden, kepala sekolah sudah cukup proaktif dalam membangun sekolah, tetapi kurang melibatkan komite sekolah.

Hasil perhitungan yang telah dilakukan menunjukan bahwa iklim kerja sekolah yang dianalisis dari dimensi iklim kerja sekolah secara fisik dan iklim kerja sekolah secara psikologis secara umum berada pada kategori sedang. Kepala sekolah dan guru sudah terjalin hubungan yang harmonis, tetapi kurang mendukung dana kegiatan. Faktor kinerja individu sangat dipengaruhi oleh dukungan iklim kerja yang meliputi pelatihan, pengembangan, peralatan, teknologi, standar kinerja, manajemen dan rekan kerja. Dukungan iklim organisasi ini diartikan sebagai iklim kerja. Jika keseluruhan yang terdapat dalam sekolah dioptimalkan maka akan dapat mewujudkan kinerja individu yang optimal pula.

Data di atas menggambarkan suasana kondusif SMK Negeri yang dibutuhkan untuk peningkatan kinerja guru dalam upaya meningkatkan kualitas pendidikan belum tercipta secara optimal. Oleh karena itu, iklim kerja sekolah harus ditingkatkan dengan berbagai pendekatan yang rasional di antaranya adalah; pendekatan organisasi, dan pendekatan individu. Gambaran aktual kinerja guru berada pada kecenderungan umum kategori cukup baik dari skor ideal. Dengan rincian dimensi perencanaan pembelajaran pada kategori skor cukup baik, pelaksanaan pembelajaran dan evaluasi pada kategori sedang.

Berdasarkan data tersebut, secara umum kinerja guru dalam pembuatan program pembelajaran sudah cukup baik, tetapi untuk pembuatan materi pengayaan secara umum masih kurang. Kemampuan pengembangan program pembelajaran oleh guru harus selalu ditingkatkan karena merupakan bagian yang tidak dapat dipisahkan dari kegiatan proses pembelajaran. Melalui perencanaan pembelajaran yang baik seorang guru akan lebih mudah dan terarah dalam melakukan kegiatan pembelajaran yang pada akhirnya akan meningkatkan prestasi peserta didik. Kinerja guru adalah kemampuan yang ditunjukkan oleh guru dalam melaksanakan tugas atau pekerjaannya. Kinerja guru dikatakan baik dan memuaskan apabila tujuan yang dicapai sesuai dengan standar yang telah ditetapkan. Tugas guru pada prinsipnya terkandung dalam kompetensi seorang guru. Tiga dimensi umum kompetensi yang saling menunjang dan membentuk kompetensi profesional tenaga kerja kependidikan, yaitu kompetensi pribadi, kompetensi profesional, dan kompetensi kemasyarakatan/sosial.

Manfaat lain dari perencanaan pembelajaran adalah membantu disiplin kerja yang baik, suasana pembelajaran lebih menarik, proses pembelajaran yang terorganisir dengan baik, relevan dan akurat sehingga pembelajaran menjadi efektif. Rencana pembelajaran juga akan membantu guru dalam mengorganisasikan materi standar, mengantsipasi peserta didik dan masalah yang mungkin timbul dalam proses pembelajaran. Tanpa persiapan dan proses pembelajaran menjadi kurang efektif. 
Berdasarkan hasil penelitian, dimensi pelaksanaan pembelajaran mendapatkan persentasi yang lebih kecil daripada pembuatan program pembelajaran termasuk kategori sedang. Hal ini berarti masih banyak guru produktif di SMK Negeri Kabupaten Indramayu yang kurang memperhatikan kualitas dalam melaksanakan proses pembelajaran. Pada saat pembukaan proses pembelajaran masih banyak guru yang tidak mengemukakan tujuan pembelajaran dan acuan materi pembelajaran. Tujuan pembelajaran harus dipahami oleh setiap peserta didik sejak awal proses pembelajaran. Dengan demikian, para peserta didik mendapat gambaran kompetensi apa yang harus diperolah pada setiap segmen proses pembelajaran. Proses pembelajaran menjadi lebih terarah dan lebih efektif. Apersepsi yang berfungsi menghubungkan materi sebelumnya dengan materi yang akan disampaikan secara umum masih banyak guru yang mengabaikannya. Pada saat menutup proses pembelajaran, secara umum masih banyak guru yang tidak memberi kesimpulan dan tindak lanjut.

Hasil perhitungan yang telah dilakukan menunjukan bahwa kepemimpinan kepala sekolah yang terdiri dari aspek kepribadian, kemampuan pengambilan keputusan, kemampuan berkomunikasi, kemampuan memberi motivasi dan pendelegasian wewenang, mempunyai pengaruh positif yang signifikan terhadap kinerja guru. Hubungan antar variabel tersebut ditunjukan pula oleh koefisien korelasi yang termasuk kategori kurang baik. Koefisien determinasi mempunyai pengartian bahwa kinerja mengajar guru ditentukan oleh kepemimpinan kepala sekolah dan ditentukan oleh variabel lain.

Berdasarkan hasil perhitungan diatas menunjukan bahwa kepemimpinan kepala sekolah berpengaruh terhadap kinerja mengajar guru dalam konteks penelitian yang dilaksanakan menunjukan kebenaran secara ilmiah. Hasil perhitungan terhadap iklim kerja sekolah yang terdiri dari dimensi iklim fisik, dan iklim psikologis, mempunyai pengaruh positif yang signifikan terhadap kinerja mengajar guru. Hubungan antar variabel tersebut ditunjukan pula oleh koefisien korelasi yang termasuk kategori rendah. Koefisien determinasi mempunyai pengertian bahwa kinerja mengajar guru ditentukan oleh iklim kerja sekolah dan ditentukan oleh variabel lain.

Berdasarkan hasil perhitungan diatas menunjukan bahwa iklim kerja sekolah berpengaruh terhadap kinerja mengajar guru dalam konteks penelitian yang dilaksanakan menunjukan kebenaran secara ilmiah. Hasil perhitungan yang telah dilakukan menunjukkan bahwa variabel kepemimpinan kepala sekolah secara parsial maupun secara simultan mempunyai pengaruh yang signifikan terhadap kinerja mengajar guru. Pengaruh kepemimpinan kepala sekolah dan iklim kerja sekolah terhadap kinerja mengajar guru ditunjukan berkorelasi cukup baik. Hal ini secara simultan, kepemimpinan kepala sekolah dan iklim kerja sekolah turut menentukan kinerja mengajar guru dan dipengaruhi oleh faktor lain. 
Hasil pembahasan yang dikemukakan di atas maka terdapat beberapa implikasi yang berkaitan dengan kinerja mengajar guru sebagai berikut:

1. Kondisi aktual kepemimpinan kepala sekolah berada pada kategori sedang atau di bawah cukup dan pengaruhnya terhadap kinerja mengajar guru rendah. Kondisi ini belum dapat sepenuhnya mendukung peningkatan kinerja guru. Oleh karena itu fungsi, dan peranan kepala sekolah sebagai EMASLIM-F harus lebih ditingkatkan. Kepala sekolah harus memiliki standar kompetensi minimal yang telah ditetapkan oleh pemerintah yakni: ompetensi kepribadian, manajerial, kewirausahaan, supervisi dan sosial. Kepala sekolah sebagai pemimpin selain harus memiliki kepribadian dan integritas yang baik juga harus visioner yang mampu membuat perubahan sekolah ke arah yang lebih baik. Kepala sekolah sebagai leader seharusnya memiliki kemampuan pengambilan keputusan yang baik, mampu mengkomunikasikan visi, memotivasi guru dan mampu mendelegasikan wewenang dengan baik.

2. Kondisi aktual iklim kerja sekolah yang dibutuhkan untuk memberi inspirasi dan motivasi mengajar guru termasuk dalam kategori rendah dan pengaruhnya terhadap kinerja mengajar guru juga rendah. Untuk peningkatan kinerja guru maka iklim kerja sekolah harus diupayakan lebih baik lagi. Lingkungan fisik sekolah harus diupayakan memberi kesejukan dan kenyamanan. Sarana-prasarana umum, ruang kantor, ruang kelas dan peralatannya harus dilengkapi secara berkala. Lingkungan psikologis seperti kualitas manajemen sekolah, rasa kekeluargaan dan dukungan harus ditingkatkan.

3. Kondisi aktual kinerja mengajar guru hanya mencapai kategori cukup baik sehingga harus ditingkatkan. Untuk meningkatkan kinerja guru maka faktor-faktor yang mempengaruhinya harus ditingkatkan. Unsur motivasi kerja termasuk kepemimpinan kepala sekolah dan iklim kerja sekolah harus lebih baik.

Dalam upaya meningkatkan kualitas pendidikan melalui kinerja guru, dibutuhkan sosok kepala sekolah yang memiliki kemampuan minimal seperti yang tertuang dalam Permendiknas Nomor 13 Tahun 2007, tentang Standar Kompetensi Kepala Sekolah yakni memiliki kompetensi kepribadian, manajerial, kewirausahaan, supervisi dan sosial. Para kepala sekolah harus menjadi pemimpin yang visioner, mengarahkan, dan memotivasi guru untuk mau dan mampu bekerja dengan baik.

Menurut Mulyasa (2003), kepala sekolah yang efektif adalah kepala sekolah yang: (1) mampu memberdayakan guru untuk melaksanakan proses pembelajaran dengan baik, lancar dan produktif; (2) dapat menyelesaikan tugas dan pekerjaan sesuai dengan waktu yang telah ditetapkan; (3) mampu menjalin hubungan yang harmonis dengan masyarakat sehingga dapat 
melibatkan mereka secara aktif dalam rangka mewujudkan tujuan sekolah dan pendidikan; (4) berhasil menerapkan prinsip kepemimpinan yang sesuai dengan tingkat kedewasaan guru dan pegawai lain di sekolah; (5) bekerja dengan tim manajemen; (6) berhasil mewujudkan tujuan sekolah secara produktif sesuai dengan ketentuan yang telah ditetapkan.

Untuk mendapatkan sosok kepala sekolah yang diharapkan, pertama-tama tergantung pada perbaikan perekrutan, pelatihan, status sosial, dan kondisi para kepala sekolah, mereka membutuhkan pengetahuan dan keterampilan, karakter personal, prospek profesional, dan motivasi yang tepat jika ingin memenuhi harapan stakeholder.

Sejalan dengan upaya untuk meningkatkan fungsi dan peranan kepala sekolah sebagai pemimpin, Danny Meirawan (2010:112-117), mengemukakan bahwa langkah pertama sekecil apapun seorang kepala sekolah seyogianya harus mempunyai visi, misi dan program utama sekolah. Langkah kedua kepala sekolah harus piawai dalam pengambilan keputusan yang berorientasi budaya atau dinamika sistem nilai yang berlaku dimana sekolah berada. Ketiga harus pandai mengkomunikasikan keputusan dan menginformasikan keputusan yang dibuat sendiri maupun keputusan partisipatif yang melibatkan berbagai pihak. Langkah ketiga kepala sekolah harus mampu menggerakan sumber daya manusia yang ada supaya mampu dan mau bekerja dan beradministrasi dengan baik.

Dalam upaya pemberdayaan guru oleh kepala sekolah, Stewart (1998), mengatakan enam cara yang dapat digunakan pemimpin dalam mengembangkan pemberdayaan staf/bawahan (guru), yakni: meningkatkan kemampuan staf/bawahan (enabling), memperlancar (facilitating) tugas mereka, konsultasi (consulting), bekerjasama (collaborating), membimbing (mentoring) bawahan, dan mendukung (supporting). Tetapi apapun cara yang ditempuh oleh pemimpin dalam memberdayakan staf/bawahan, menurut Sarah Cook dan Steve Macaulay (1997), kepemimpinan yang memberdayakan perlu mengacu pada empat dimensi, yaitu visi, realita, orang (manusia), dan keberanian.

Berdasarkan temuan dalam penelitian dan konsep di atas, maka kepada para kepala sekolah agar: (1) menganalisis dan mengidentifikasi permasalahan dan potensi yang ada di sekolah sebagai titik tolak dan untuk menentukan skala prioritas dalam upaya meningkatkan kinerja guru yang optimal, (2) menjalin hubungan komunikasi yang lebih baik dengan para guru sehingga setiap permasalahan yang muncul dapat segera di atasi dengan bijaksana.

Kondisi aktual kinerja mengajar guru hanya mencapai kategori cukup baik sehingga harus ditingkatkan. Untuk meningkatkan kinerja guru, maka faktor-faktor yang mempengaruhinya harus ditingkatkan. Unsur motivasi kerja termasuk kepemimpinan kepala sekolah dan iklim kerja sekolah harus lebih baik. Pengetahuan, keterampilan, status sosial dan kondisi guru harus ditingkatkan dengan berbagai upaya sesuai dengan kemampuan sekolah, 
misalnya dengan memberikan pelatihan, studi banding dan pertemuan ilmiah. Hal ini sejalan dengan UNESCO yang menyatakan bahwa memperbaiki mutu pendidikan tergantung pada perbaikan perekrutan, pelatihan, status sosial, dan kondisi para guru, mereka membutuhkan pengetahuan dan keterampilan, karakter personal, prospek profesional, dan motivasi yang tepat jika ingin memenuhi harapan stakeholder.

Kompetensi memiliki korelasi positif dan memberikan pengaruh yang signifikan. Sehingga pihak sekolah sebaiknya lebih meningkatkan kemandirian dari para guru dengan memberikan segala keleluasaan untuk mengambil keputusan sehubungan dengan wewenang yang dimiliki oleh guru. Selain itu, dalam pengambilan keputusan yang bersifat operasional pengajaran direkomendasikan untuk selalu melibatkan para guru. Besarnya pengaruh dari iklim kerja terhadap kinerja guru dapat dijadikan bahan pertimbangan dari fihak sekolah untuk lebih meningkatkan iklim kerja agar semakin meningkatkan kinerja dari para guru.

Motivasi kerja memberikan dorongan yang cukup berarti dalam peningkatan kinerja seseorang. Dengan motivasi kerja ini mendorong guru untuk mengarahkan semua kemampuannya serta energi yang dimilikinya demi mencapai prestasi kerja yang optimal. Motivasi kerja selalu terkait dengan perilaku guru dalam bekerja, termasuk didalamnya dorongan atau keinginan untuk bekerja lebih giat dan menyelesaikan pekerjaan dengan cara yang terbaik. Berdasarkan pembahasan di atas, penulis berkeyakinan bahwa sikap kerja yang positif akan menghasilkan kinerja individu yang optimal. Dengan demikian, dapat dibuktikan baik secara teoretis maupun praktis bahwa iklim kerja benar-benar memberikan kontribusi yang nyata terhadap kinerja guru. Hubungan tersebut dapat dijelaskan bahwa seorang pekerja yang memiliki motivasi berprestasi yang tinggi, cenderung dia memiliki prestasi kerja yang tinggi. Sebaliknya, seorang pekerja yang prestasi kerjanya rendah dimungkinkan oleh motivasi berprestasinya rendah. Hal ini membuktikan bahwa mtoif berprestasi secara meyakinkan berkontribusi terhadap kinerja.

\section{KESIMPULAN}

Berdasarkan hasil penelitian yang dilakukan, dapat diambil beberapa kesimpulan bahwa kepemimpinan kepala SMK Negeri se-Kabupaten Indramayu yang meliputi dimensi kepribadian, kemampuan pengambilan keputusan, kemampuan berkomunikasi, memberi motivasi dan pendelegasian wewenang berada pada kategori sedang. Kondisi aktual iklim kerja sekolah berada pada kecenderungan umum kategori sedang. Baik iklim kerja sekolah secara fisik maupun iklim kerja sekolah secara psikologis ke duanya termasuk pada kategori sedang. Kinerja mengajar guru berada pada kecenderungan umum kategori cukup baik. Dengan rincian dimensi perencanaan pembelajaran pada kategori cukup baik, pelaksanaan 
pembelajaran dan evaluasi pada kategori sedang atau kurang dari cukup. Kepemimpinan Kepala Sekolah berpengaruh positif terhadap kinerja guru tetapi rendah dan kurang cukup memotivasi kinerja guru. Pengaruh iklim kerja sekolah terhadap kinerja guru ada pada kategori rendah dan kurang cukup memotivasi kinerja guru. Kepemimpinan kepala sekolah dan iklim kerja memberikan pengaruh positif yang signifikan terhadap kinerja guru pada kategori sedang atau kurang cukup meningkatkan kinerja guru.

\section{DAFTAR PUSTAKA}

Depdiknas. (2004). Undang-undang Republik Indonesia Nomor 20 Tahun 2003 Tentang Sistem Pendidikan Nasional. Jakarta: PT. Armas Duta Jaya.

Djohar, As'ari. ( 2008). Perspektif Pendidikan Menengah dan Kejuruan dalam Menyiapkan Tenaga Kerja yang Siap Mendukung Proses Pembangunan di Berbagai Bidang. Pidato Pengukuhan Jabatan Guru Besar Tetap dalam Ilmu Pendidikan pada Jurusan Pendidikan Teknik Mesin FPTK Universitas Pendidikan Indonesia. Bandung. Tidak diterbitkan.

Gibson, James. L, John M. Ivancevich, dan James H. Donnely Jr. (1992), Organisasi: Perilaku, Struktur, dan Proses. Jakarta: Binapura Aksara.

Macaulay, Steve \& Cook, Sarah (1997). How to Improve Your Customer Service. Jakarta: PT. Gramedia.

Mangkunegara, Anwar Prabu. (2008). Perilaku dan Budaya Organisasi. Bandung: Rafika Aditama.

Meirawan, Danny. (2010). Kepemimpinan dan Manajemen Pendidikan Masa Depan. Bogor: IPB Press.

Mulyasa, E. (2003 ). Menjadi Kepala Sekolah Profesional. Bandung: PT Remaja Rosda Karya.

Rivai, Veithzal. (2007). Kepemimpinan dan Prilaku Organisasi. Jakarta: PT. Raja Grafindo Persada.

Sallis, Edward. (2006). Total Quality Management in Education. Edisi Indonesia Cetakan III. Jogjakarta: IRCiSoD.

Sudjana, N. (2009). Penilaian Hasil Proses Belajar Mengajar. Bandung: PT. Remaja Rosdakarya.

Sukmara, D. (2007). Implementasi Life Skill dalam KTSP. Bandung: Mughni Sejahtera.

Syah, M. (2010). Psikologi Pendidikan. Bandung: PT. Remaja Rosdakarya.

Wahjosumijo. (2007). Kepemimpinan dan Motivasi. Bandung: Gahlia Indonesia.

Yuniarsih, Tjutju dan Suwatno. (2008). Manajemen Sumber Daya Manusia. Bandung: Alfa Beta.

Uno, B.H. (2010). Teori Motivasi \& Pengukurannya. Jakarta: Bumi Aksara. 